Brit. J. vener. Dis., (1960), 36, 134.

\title{
THE REALITIES OF THE CAMPAIGN AGAINST THE VENEREAL DISEASES
}

BY

\author{
A. de FONSECA
}

Portugal

We know that the reservoir of the venereal diseases lies in the lower levels of society, whence they spread up the rungs of the social ladder. The higher. one goes up the social scale the fewer cases one meets.

At the lower levels is found the great army of common prostitutes. By the term "common prostitute" is meant a woman who lives only by prostitution and advertises her wares to attract attention. On the assumption that public prostitutes are the chief source of infection, the main effort has been devoted to the medical examination of these women and the treatment of those who are infected. This end is not always attained successfully for various reasons, the most common obstacles being:

The difficulty of identifying all the women;

The difficulty of carrying out medical examinations at short intervals;

The tendency of such women to migrate from place to place;

The existence of clandestine prostitution, which takes many forms and is found in all classes of society.

By the term "clandestine prostitute" is meant one who has another occupation which covers up her sexual activities, or who disguises them by some other means.

With the material improvement which has come to those levels of society where the public prostitute is most often seen, she is apt to become a clandestine operator, finding that she can achieve her object more easily by this means.

In a community with a high standard of living, common prostitutes are few or non-existent, and prostitution goes underground, becoming clandestine in the fullest sense of the word, since it is so well hidden that it appears to have vanished altogether.

In the great upheavals of population which are going on everywhere, clandestine prostitution is particularly important in the spread of venereal disease. This is most noticeable in the rise in the number of cases of these diseases in places where large numbers gather for fairs and festivals and in holiday resorts.

As far as sexual hygiene is concerned, the attitude of those who argue for and against the organization or abolition of prostitution is out of date. Prostitution may be discussed from the social or moral point of view, but it should not be regarded as being confined to a particular group on the fringes of society. The common prostitute is sexually less important than the clandestine or the libertine.

A man infected by a prostitute soon notices the fact and seeks treatment at a clinic, provided information regarding the symptoms of venereal disease is well publicised.

Because the early symptoms of venereal disease are so much less obvious in women, infected females, whether prostitutes or not, do not usually seek advice until the disease happens to become acute and troublesome. It is mostly those women in whom the disease gives rise to genital symptoms who are seen and treated at the gynaecological clinics. Very often, because the disease is latent, infected women do not seek treatment because there are no symptoms to prompt them to visit a doctor, and it may be only by chance that a consultation for some other complaint leads to the discovery of the venereal infection.

It appears to us that the recent spread of venereal disease is due to the factors outlined above, and also perhaps to a decreased use of penile sheaths which were formerly employed as a protection against venereal disease but are now hardly used except as contraceptives.

The important part played by homosexual practices should also be remembered.

These things being so, we feel that the campaign 
against venereal disease should be based on individual efforts in every branch of medicine, apart from the work of specialists and special clinics. It is at the first consultation at which a patient is discovered, along with the source of his infection and the women he may have infected, that the true antivenereal battle should begin. There must be a rapid search for these other contacts so that they can be examined and treated.

We therefore consider that the programme of an anti-venereal campaign should be drawn up as follows:

(1) Standardization of the diagnostic methods to be used in all clinics of all specialties, whatever the symptoms which have caused the patient to seek a consultation. These standards should be adopted as a routine and every clinic should have special facilities to establish the diagnosis. Private practitioners should be able to avail themselves of these facilities without trouble. It follows that the diagnosis and treatment should be free.

(2) Diagnostic centres and reference laboratories should be at the disposal of all doctors and medical organizations. In places where the need justifies it, diagnostic centres should be set up, in collaboration with the dermato-venereological departments in clinics and hospitals or independently if this is more convenient, staffed by public health nurses, where those thought to be infected can be diagnosed as quickly as possible. Such persons can then be tactfully directed to a clinic or private practitioner for treatment.

(3) Compulsory medical examination before a marriage licence is granted; the certificate should record that the tests have been carried out but without mentioning the result.

(4) Compulsory medical examination for all candidates for employment by the state and for all emigrants; the certificate should show the results of the tests, not to disqualify the candidate but to ensure that the public health authorities can see that the necessary treatment is given. These tests should of course, be done free of charge.

Such rules as these can be applied in any country, whatever the local customs and medical arrangements may be. Above all they are inexpensive, and would cost far less than those at present in force in many places.

\section{Actualisation de la lutte antivénérienne Résumé}

L'action anti-vénérienne requiert actuellement les dispositions suivantes:

(1) Généralisation et uniformisation des méthodes de diagnostic à adopter dans toutes les cliniques, indépendamment de la spécialité et du motif clinique ayant amené le malades à la consultation.

Ces normes seraient adoptées comme pratique de routine et les services cliniques auraient des facilités spéciales pour les appliquer dans leurs consultations et dans leurs laboratoires privés, ou dans d'autres spécialement outillés et préparés à cette fin.

Les médecins faisant de la clinique privée pourraient, eux aussi, sans difficulté, avoir recours à ces laboratoires.

Il est évident que, à cet effet, toutes les analyses et tous les médicaments nécessaires devraient être gratuits.

(2) Organisation de services d'enquête, centraux, mis à la disposition de tous les médecins et services médicaux.

Dans les localités oû les nécessités le justifieraient, seraient organisés des services d'enquête, intégrés dans l'un des principaux services de la spécialité de dermatovénéréologie, de dispensaire ou hospitalier, ou indépendants de toute clinique selon ce qui conviendra le mieux, composés d'infirmières de la santé publique, oû seraient signalées, le plus rapidement possible, les personnes considérées comme malades. Elles seraient immédiatement recherchéés et orientées, aved le tact le plus délicat, vers une clinique ou un médecin privé.

(3) Mesures de prophylaxie par l'obligation de certificats médicaux pré-nuptiaux, indiquant que les analyses appropriées ont été faites, mais sans mention des résultats.

(4) Obligation de certificats médicaux pour tout postulant a un emploi officiel, examens d'aptitude physique de toute nature et pour toute fin, ainsi que pour tous les émigrants. Ces certificats mentionneraient évidemment les résultats des analyses, non pour éliminer les candidats, mais pour que les autorités sanitaires chargées de la lutte antivénérienne puissent surveiller l'exécution des traitements nécessaires.

Il est évident que tous ces certificats seraient délivrés gratuitement par tous les services cliniques, ou seulement par ceux qui seraient désignés à cette fin.

La lutte antivénérienne doit consister, fondamentalement, dans une action médicale individuelle s'exerçant dans tout le domaine médical, indépendamment de la spécialité et des services cliniques. C'est à partir de la consultation, une fois le malade identifié et, grâce à lui, connue ou suspectée la personne qui l'a contaminé, ainsi que celles qu'il pourrait avoir contaminées, que commencera la lutte antivénérienne proprement dite par la recherche rapide de ces personnes afin de pouvoir les examiner, où elles le désireront, puis de soigner celles qui se révèleront malades. 